Pak. j. sci. ind. res. Ser. A: phys. sci. 2020 63A(1) 40-47

\title{
Eco-Friendly Degradation of Reactive Blue Dye Enriched Textile Water by Floating Treatment Wetlands (FTWs) System Applying the Strategy of Plant-Bacteria Partnership (Part-B)
}

\author{
Muhammad Qamar Tusief ${ }^{\text {ab* }}$, Mumtaz Hasan Malik ${ }^{\mathrm{b}}$, Muhammad Mohsin ${ }^{\mathrm{c}}$, \\ Hafiz Naeem Asghar ${ }^{d}$, Muhammad Iqbal ${ }^{\mathrm{e}}$ and Nasir Mahmood ${ }^{\mathrm{a}}$ \\ ${ }^{a}$ Department of Fibre and Textile Technology, University of Agriculture, Faisalabad, Pakistan \\ ${ }^{\mathrm{b}} \mathrm{S}$ chool of Textile and Design, University of Management and Technology Lahore, Pakistan \\ ${ }^{\mathrm{c}}$ Department of Textile Engineering, University of Engineering and Technology, Lahore \\ (Faisalabad Campus), Pakistan \\ dinstitute of Soil and Environmental Sciences, University of Agriculture Faisalabad, Pakistan \\ ${ }^{\mathrm{e}}$ Department of Food Engineering, University of Agriculture, Faisalabad, Pakistan
}

(received March 6, 2019; revised June 17, 2019; accepted June 26, 2019)

\begin{abstract}
Textile dye enriched effluents have been credited to be heavily polluted and highly hazardous to environment. Cleaning of textile wastewater from these dangerous pollutants is a deeply concerned issue of the industry. Various physico-chemical and biological techniques are being practiced to remediate these effluents. But all these strategies have limitations at any corner of their application. Floating treatment wetlands (FTWs) are acknowledged as economical treatment options for various kinds of wastewater. Their efficacy has been ascribed in many lab-scale and pilot-scale studies, however scarceness of published data lies in sense of application of this technique using free floating aquatic plants for treating major primary reactive blue dye enriched textile water. So, the present study attempted to evaluate the performance of this method using two free floating aquatic plants, "Eichhornia crassipes" and "Pistia stratiotes" to develop a lab scale FTWs system augmented with two pollutant degrading and plant growth promoting bacteria, "Bacillus cereus" and "Bacillus subtilis" after four retention times, 0, 24, 48 and $72 \mathrm{~h}$. One control and eight FTW treatment reactors were established containing plants and bacteria separately or in combination. This system was applied to treat reactive blue dye enriched textile wastewater prepared synthetically. A remarkable reduction in pollutant indicating parameters, BOD, COD and colour concentration was observed for treatment reactor having Eichhornia crassipes and Bacillus cereus combination for $72 \mathrm{~h}$ retention time. All this stamped the authenticity of this plant-microbial enhanced FTWs technique to treat textile wastewater and opened an era of its on-site application.
\end{abstract}

Keywords: floating treatment wetlands, plant-bacteria partnership, textile wastewater treatment, reactive blue dye

\section{Introduction}

Textile industry is the key player in economy of many countries especially developing ones like Pakistan. However, it is high source of water pollution due to the discharge of its untreated or partially treated wastewater in nearby water bodies (Noreen et al., 2017). Textile effluents are the complex mixture of variant organic and inorganic pollutants, chemicals and dyes which are highly toxic to aquatic and environment health. This hazardousness poses severe threat to developing countries, who lack capability to efficiently treat such toxicants cost effectively. This results in the form of contaminating their valuable water resources (Khandare et al., 2013). Major sector of textile generating huge

*Author for correspondence; E-mail: qamartosief@yahoo.com quantity of water is textile dyeing and processing industry. About 70 billion tons of wastewater is generated by this industry each year (Moga et al., 2018). In dyeing industry reactive dyes are most commonly used especially to dye cotton related products (Sudha et al., 2014). Among all reactive dyes blue dye is a major primary dye that has been observed highly resistant to chemical oxidation and difficult to break down due to its aromatic anthraquinone structure. It has been well recognized that more than $15 \%$ dye stuff do not bind to the textile product and is washed out resulting in dye enriched wastewater (Annuar et al., 2009). These dyes residues in wastewater become the source to increase BOD (biological oxygen demand), COD (chemical oxygen demand) and colour concentration in the receiving 
water bodies (Lie et al., 2012). Moreover, the polluted water when discharged in channels seeps and pollutes the ground water. When this contaminated water is used to irrigate the fields of various crops and vegetables, the pollutants enter the food chain. Ultimately, when human uses the polluted ground water and food, they cause serious health hazards by leading to diseases like cholera, typhoid, dysentery, guinea worm disease, cancer, tumor, brain diseases etc. Similarly, different kinds of dyes and pigments of organic nature, salts, alkalis, acids, bleaching and finishing agents also cause significant hazardous effects on the health of biota (Imtiazuddin et al., 2012).

Many physical, chemical and biological techniques are successful in treating textile wastewater but mostly they have limitations in sense of their high demand of operational costs, labour administration, engineering skills and production of additional waste in form of sludge that requires further safe disposal (Srinivasan et al., 2014). Contrary to all these draw backs of existing physico-chemical mechanisms to treat textile effluents, phyto-remediation has been acknowledged as an effective tool to treat textile wastewater in simple, less expensive and green way (Choo et al., 2006). Application of floating treatment wetlands (FTWs) as a well designed and engineered way of phyto-remediation has been measured to be an effective, innovative, reliable, cost effective and eco-friendly technique to treat different types of wastewaters like municipal, sewage, domestic and industrial (Arshad et al., 2017; Ijaz et al., 2015; Faulweter et al., 2011). In this technique plants roots hang down into water column and provide both biological and mechanical filtering of wastewater. Biological filtering is the result of bacterial degradation of pollutants, while mechanical filtering is carried out by dense root system of plants in the form of sedimentation, adsorption, filtration, etc. (Zhang et al., 2016; Merkhali et al., 2015). Additionally this system provides aesthetic beauty to the area along with acting as habitation for fish and many other life forms (Ijaz et al., 2015). Moreover, this is the source of generating significant amount of biomass that can be used for bioenergy purposes (Shahid et al., 2018). Many additional approaches have been proposed for the performance enhancement of FTWs, among of them inoculation of pollutant degrading and plant growth promoting bacteria has been found more effective (Saleem et al., 2018). Under this plant-bacteria synergism, plants provide habitat and nutrients to bacteria; while in return, bacteria boost up plant growth and degrade organic pollutants due to their metabolic activities. Many studies regarding augmentation of FTWs through plant-microbe interactive mechanism have been carried out for remediation of different wastewaters (Rehman et al., 2018; Watharkar et al., 2015). In most of them emergent plants were vegetated on free floating raft. However, application of this technique using free floating aquatic plants assisted with plant growth promoting and pollutant degrading bacteria, for remediation of pure reactive blue dye enriched textile wastewater, finds paucity. Hence the present study endeavored to have performance evaluation of this system using two free floating aquatic plants (Eichhornia crassipes and Pistia stratiotes) with augmentation of two pollutant degrading and plant growth promoting bacteria (Bacillus cereus and Bacillus subtilis) to treat purely reactive blue dye enriched textile wastewater.

\section{Materials and Methods}

Synthetic solution of reactive blue (Bezaktiv HP-R) was prepared at lab scale following standard recipe for $0.1 \%$ shade depth. Then this solution was transferred to transparent polyethylene containers $(39 \mathrm{~cm} \times 28 \mathrm{~cm}$ $\times 20 \mathrm{~cm}$ ) of 10-12 liter capacity. FTWs system was designed by vegetating two free floating aquatic plants Eichhornia crassipes and Pistia stratiotes in these containers. The system was amplified by inoculating two bacteria, "Bacillus cereus" and "Bacillus subtilis" in these containers Fig. 1 in order to develop 9 treatment reactors as per the decided detail given in section "Designing of FTWs Experimental reactors". The capability of these bacterial strains regarding plant growth promotion and pollutant degradation has been well reported in many previous studies (Asghar et al., 2017; Nair and Swarnalatha, 2015). The interaction of these bacteria with plants was made by dipping plants in $500 \mathrm{~mL}$ broth of each bacterium for $40 \mathrm{~min}$. Then these plants were transferred to each treatment reactor according to their decided number.

Different aspects of experimental study have been explained below:

Reactive blue dye enriched solution preparation. Reactive blue (Bezaktiv HP-R) dye enriched textile wastewater solution of $0.1 \%$ shade depth was prepared synthetically at lab scale according to the following recipe:

Dye $1 \mathrm{~g} / \mathrm{L}$, Glauber's salt $5 \mathrm{~g} / \mathrm{L}$ and soda ash $0.4 \mathrm{~g} / \mathrm{L}$ 


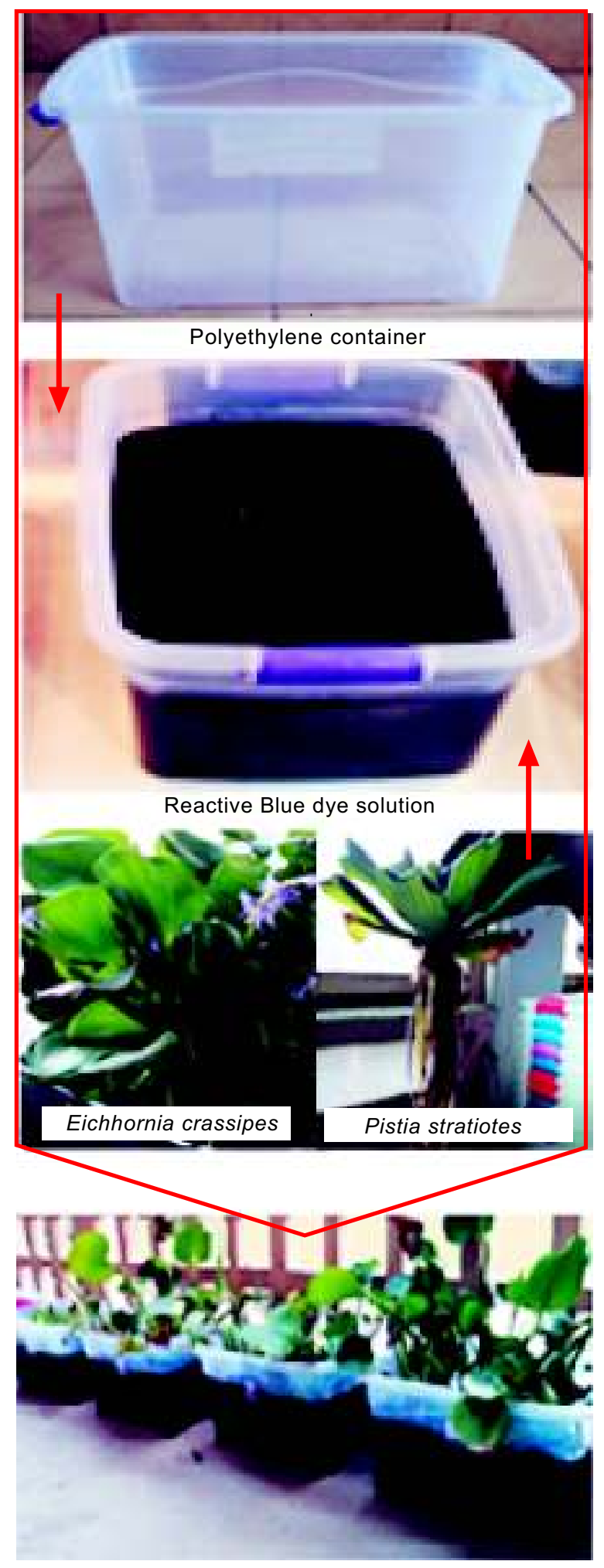

Prepared FTWs system

Fig. 1. Various components and designing of FTWs system.
Collection of effluent degrading bacterial strains. Two type of bacterial strains "Bacillus cereus" and "Bacillus subtilis" were taken from Soil Microbiology and Biochemistry lab of Institute of Soil and Environmental Sciences, University of Agriculture Faisalabad, Pakistan, where they were isolated (Rafique, 2015) using general purpose agar media (glucose peptone agar media) applying dilution plate technique. Media plates were inoculated with soil solution and incubated at $28 \pm 2{ }^{\circ} \mathrm{C}$ for $72 \mathrm{~h}$. Colony farming units (CFU/g soil) from each soil sample were calculated. The bacterial isolates were assayed for their potential to biodegrade polycyclic aromatic hydrocarbon using Bushnell-Haas broth in 24-well microtiter plates (Hanson et al., 1993). For the verification of bacteria properties regarding plant growth promoting, they were also tested for ACCdeaminase activity through method (modified) described by Jacobson et al. (1994). These bacteria have also been reported by many previous researchers (Ijaz et al., 2015; Nair and Swamalatha, 2015) to have characteristics of textile effluent degrading and plant growth promotion.

Plant selection. Locally available plants having immunity with the native environmental conditions are appreciable to use for this treatment technique. So, two abundantly occurring plants, in and surrounding of Lahore and Faisalabad (The textile industry hub of Pakistan) were selected for conducting this research study. Adult plants were collected from nearby fresh and wastewater bodies and then stored in circular tubs of diameter $76 \mathrm{~cm}$ with $30 \mathrm{~cm}$ depth under ambient conditions at the Department of Fibre and Textile Technology, University of Agriculture Faisalabad. For making them able to survive in pure textile water, they were watered with textile wastewater and tap water in increasing ratio i.e. 0:100, 20:80, 40:60, 60:40, 80:20 and 100:0, respectively. The plants flourished well after getting immunity within 10 days and doubled their population.

The worth of collected bacterial strain and plants was tested for degrading textile wastewater at lab scale. Various operational parameters like hydraulic retention time, bacterial strains, plants types and their interaction were analyzed for getting their optimum levels. These factors were selected in the range as given in Table 1.

Designing of FTWs experimental reactors. One control and eight experimental FTWs treatment reactors were designed with the following specifications:

$\mathrm{C}=$ control (only reactive blue dye enriched solution) $\mathrm{T} 1=$ dye solution $+\mathrm{P} 1$ (plant 1: Eichhornia crassipes) 
Table 1. Parameters and their values selected for the current study

\begin{tabular}{lllll}
\hline \hline Textile effluent source & Retention time $(\mathrm{h})$ & Bacterial strains & Plant types & Reactors description \\
\hline Reactive blue & TM1 $=0$ & Bacillus cereus & Eichhornia crassipes & $\mathrm{R}_{1}=$ effluent + plant \\
& TM2 $=24$ & Bacillus subtilis & Pistia stratiotes & $\mathrm{R}_{2}=$ effluent + bacteria \\
& & & $\mathrm{R}_{3}=$ effluent + plant + bacteria \\
& TM3 $=48$ & & \\
\hline \hline
\end{tabular}

$\mathrm{T} 2=$ dye solution $+\mathrm{P} 1+\mathrm{B} 1$ (bacteria 1: Bacillus cereus)

$\mathrm{T} 3=$ dye solution $+\mathrm{P} 1+\mathrm{B} 2$ (bacteria 2 : Bacillus subtilis)

$\mathrm{T} 4=$ dye solution $+\mathrm{P} 2$ (plant 2: Pistia stratiotes)

$\mathrm{T} 5=$ dye solution $+\mathrm{P} 2+\mathrm{B} 1$

$\mathrm{T} 6=$ dye solution $+\mathrm{P} 2+\mathrm{B} 2$

$\mathrm{T} 7=$ dye solution $+\mathrm{B} 1$

$\mathrm{T} 8=$ dye solution $+\mathrm{B} 2$

Testing of textile effluent. $500 \mathrm{~mL}$ sample was taken from each reactor in transparent plastic bottles after washing them thoroughly with distilled water and analyzed for determining the BOD, COD and colour concentration (CC) according to standard procedures (APHA, 2005).

Statistical analysis. The data obtained were statistically analyzed for checking overall significance of mean values, while the difference among treatment means was calculated by using least significant difference (LSD) test. Experiment was arranged according to completely randomized design (CRD) with three replications. SAS program, version STAT 9.1 of SAS Institute (Clark, 2004) was operated for all statistical applications.

\section{Results and Discussion}

Physico-chemical parameters of reactive blue dye enriched textile wastewater as affected by selected treatments (T) and retention times (TM). The data regarding analysis of variance (ANOVA) presented in Table 2 indicated significant effects $(\alpha=0.05)$ of all treatments (T) and retention times (TM) on BOD, COD and $\mathrm{CC}$ values of selected solution.

Effect of various treatments and hydraulic retention time on BOD value of reactive blue dye enriched textile wastewater. All the selected treatments and times had significant effects on BOD of reactive blue dye enriched textile wastewater. There was noted remarkable reduction in BOD value of the treated water with increasing retention time. The BOD value of wastewater for control reactor (C) at initial time TM1 $(0 \mathrm{~h})$ was found $90 \mathrm{mg} / \mathrm{L}$ that reduced to $38 \mathrm{mg} / \mathrm{L}$ for combined treatment of the water with Echhornia crassipes and Bacillus cereus bacteria (T2). This treatment combination made $57.78 \%$ reduction in BOD value of the treated water after $72 \mathrm{~h}$ retention time (TM4) as shown in Fig. 2.

The ANOVA for regression Table 3 indicated that all the retention times (TM) had significant effects $(\alpha=0.05)$ on BOD of the solution. Regression model developed disclosed that time inversely affected BOD values at the rate of 0.47 . The high degree of certainty $\left(r^{2}=0.56\right)$ ensures the best representation of the data observed by

Table 2. ANOVA of treatment and retention time for reactive blue dye enriched textile water

\begin{tabular}{|c|c|c|c|c|c|c|c|}
\hline \multirow[t]{2}{*}{ Source } & \multirow[t]{2}{*}{ DF } & \multicolumn{2}{|c|}{ Dep var BOD } & \multicolumn{2}{|c|}{ Dep var COD } & \multicolumn{2}{|c|}{ Dep var CC } \\
\hline & & $\overline{\mathrm{MS}}$ & $\mathrm{P}>\mathrm{F}$ & $\overline{\mathrm{MS}}$ & $\mathrm{P}>\mathrm{F}$ & MS & $\mathrm{P}>\mathrm{F}$ \\
\hline Model & 35 & 807.6262 & 0.0001 & 995.4696 & 0.0001 & 0.0009 & 0.0001 \\
\hline $\mathrm{T}$ & 8 & 1012.7083 & 0.0001 & 1403.8357 & 0.0001 & 0.0001 & 0.0001 \\
\hline TM & 3 & 5696.0833 & 0.0001 & 6652.0093 & 0.0001 & 0.0064 & 0.0001 \\
\hline $\mathrm{T} * \mathrm{TM}$ & 24 & 128.2083 & 0.0001 & 152.2801 & 0.0001 & 0.0002 & 0.0001 \\
\hline Error & 72 & 29.6667 & & 34.0648 & & 0.00002 & \\
\hline Corr Total & 107 & & & & & & \\
\hline
\end{tabular}

$\mathrm{T}=$ treatment $\mathrm{C}=$ control (only solution) $\mathrm{T} 1=$ solution + plant $1($ Eichhornia crassipes $) ; \mathrm{T} 2=$ solution + plant $1+$ bacteria $1($ Bacillus cereus $) ; \mathrm{T} 3=$ solution + plant $1+$ bacteria $2($ Bacillus subtilis $) ; \mathrm{T} 4=$ solution + plant $2($ Pistia stratiotes $) ; \mathrm{T} 5=$ solution + plant $2+$ bacteria $1 ; \mathrm{T} 6=$ solution + plant $2+$ bacteria $2 ; \mathrm{T} 7=$ solution + bacteria 1 and $\mathrm{T} 8=$ Solution + bacteria $2 ; \mathrm{TM}=$ retention time $(\mathrm{TM} 1=0 ; \mathrm{TM} 2=24 ; \mathrm{TM} 3=48 ; \mathrm{TM} 4=72 \mathrm{~h})$. 


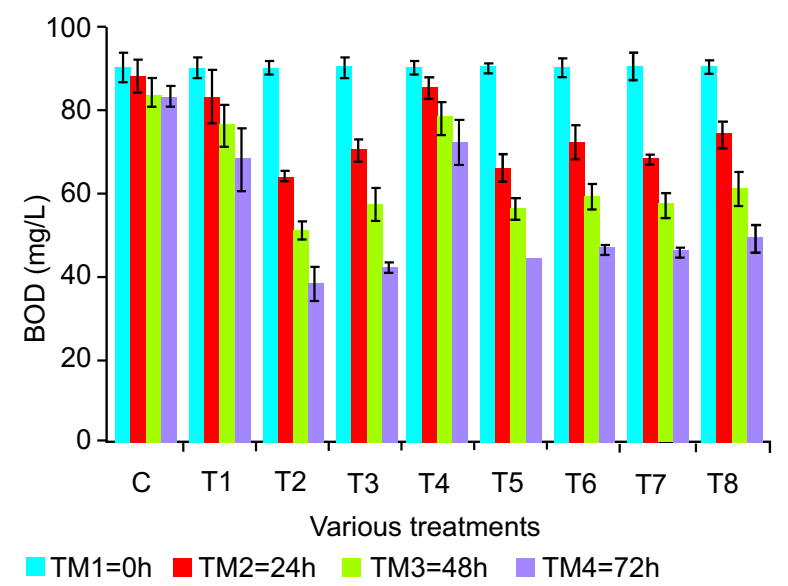

Fig. 2. Effect of various treatments for different retention times (TM) on BOD value of reactive blue dye enriched textile water.

the predicted equation (1):

$$
\mathrm{BOD}(\mathrm{mg} / \mathrm{L})=87.178-0.47 \times \mathrm{TM}(\mathrm{h})
$$

It can be derived from these observations that plantbacteria coalition degraded the textile dye enriched effluent more effectively. These results are in line with the findings of earlier studies that plant bacteria synergic mechanism reduced BOD of the solution more efficiently (Tara et al., 2019). This reduction has been credited to the increase of dissolved oxygen of the wastewater because of the presence of plants. Plants increased the oxygen concentration in the solution resulting oxidation reaction due to which the degradation of organic pollutants took place. Moreover, the bacterial inoculation enhanced this removal ability because of their aptitude to transform and decompose organic matter (Vymazal, 2010).

Effect of various treatments and hydraulic retention time on COD value of reactive blue dye enriched textile wastewater. The COD value of reactive blue dye enriched textile wastewater under treatment was found to be affected significantly by all selected treatments and times. With increase in hydraulic retention time there was found increase in reduction of COD. The maximum value of COD $(183 \mathrm{mg} / \mathrm{L})$ was noted for control reactor (C) at start of the experiment TM1 $(0 \mathrm{~h})$. This value reduced considerably up to $125 \mathrm{mg} / \mathrm{L}$ when this wastewater was treated by Eichhornica crassipes plant in synergy with Bacillus cereus bacteria (T2) after $72 \mathrm{~h}$ retention time (TM4). In Fig. 3 the calculated $31.69 \%$ reduction in COD of treated water for this treatment combination.

The ANOVA for regression Table 3 indicated that all the retention times (TM) had significant effects $(\alpha=0.05)$ on COD of the solution. Regression model so developed depicted an inverse relation between time and COD values at the rate of 0.49 . The value of degree of certainty was found high $\left(r^{2}=0.49\right)$ that ensured the best representation of the data observed by the predicted equation (2):

$$
\operatorname{COD}(\mathrm{mg} / \mathrm{L})=177.76-0.49 \times \mathrm{TM}(\mathrm{h})
$$

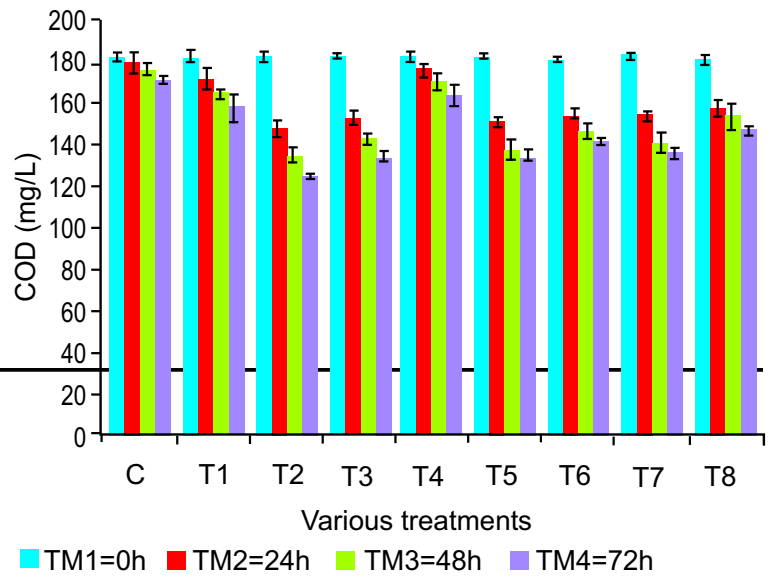

Fig. 3. Effect of various treatments for different retention times (TM) on COD value of reactive blue dye enriched textile water.

\begin{tabular}{|c|c|c|c|c|c|c|c|}
\hline \multirow[t]{2}{*}{ Source } & \multirow[t]{2}{*}{ DF } & \multicolumn{2}{|c|}{ Dep var BOD } & \multicolumn{2}{|c|}{ Dep var COD } & \multicolumn{2}{|c|}{ Dep var CC } \\
\hline & & MS & $\mathrm{P}>\mathrm{F}$ & MS & $\mathrm{P}>\mathrm{F}$ & $\mathrm{MS}$ & $\mathrm{P}>\mathrm{F}$ \\
\hline Model & 1 & 16968 & 0.0001 & 18317 & 0.0001 & 0.01930 & 0.0001 \\
\hline Error & 106 & 126.74 & & 179.032 & & 0.00012 & \\
\hline Corr Total & 107 & & & & & & \\
\hline
\end{tabular}

Table 3. ANOVA for regression analysis 
The reduction in COD of effluent is related to the fact as acknowledged previously (Patel and Adhvaryu, 2016) that the presence of plants in wastewater could deplete dissolved $\mathrm{CO}_{2}$ during the time of high photosynthetic activity. Because of this photosynthetic activity the dissolved oxygen of water increased and resulted in creation of aerobic conditions in wastewater that favoured the aerobic bacterial activity to reduce the COD. The presence of plant growth promoting bacteria in reactor booted up this reduction process. The application of plants in combination of pollutant degrading and plant growth promoting bacteria applying floating wetland technology has also been considered as an auspicious approach for BOD and COD reduction by earlier researchers (Arslan et al., 2017; Abed et al., 2017; Ijaz et al., 2016).

Effect of various treatments and hydraulic retention time on colour concentration value of reactive blue dye enriched textile wastewater. The data disclosed significant impact of all treatments and retention time on color degradation of reactive blue dye enriched textile wastewater. The results for colour concentration percentage (CC \%) of wastewater Fig. 4 exposed off its maximum value $(0.1 \%)$ at the start of the experiment (TM1) before any kind of treatment. This value reduced to $0.043 \%$ for Eichhornia crassipes and Bacillus cereus combined treatment (T2) of the wastewater for $72 \mathrm{~h}$ retention time (TM4). This treatment combination resulted in $57 \%$ degradation in colour concentration of the treated water.

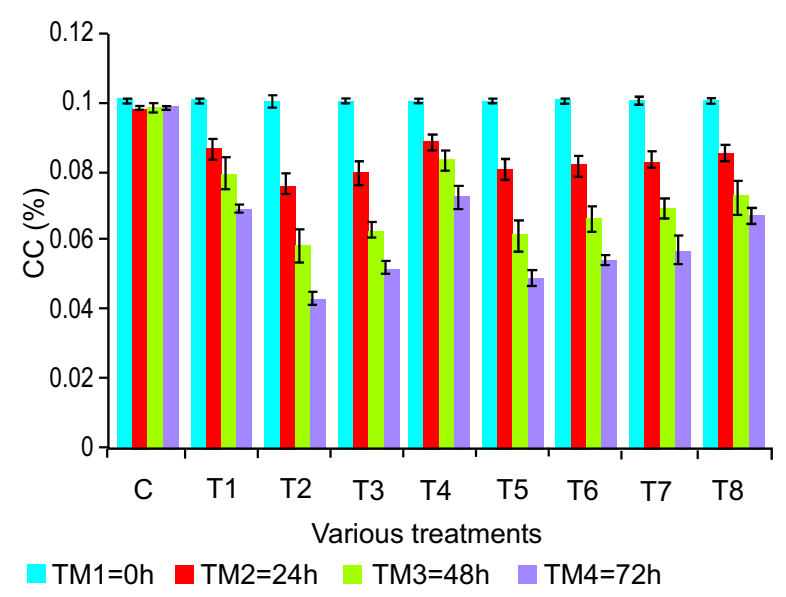

Fig. 4. Effect of various treatments for different retention times (TM) on CC of reactive blue dye enriched textile water.
The regression analysis Table 3 indicated significant $(\alpha=0.05)$ effect of time (TM) on color concentration (CC) of the solution. The developed regression model in this respect showed that time inversely affected CC values at the rate of 0.00050 . Degree of certainty resulted $\operatorname{high}\left(\mathrm{r}^{2}=0.60\right)$ in value depicted the best representation of the data observed by the predicted equation (3):

$$
\mathrm{CC}(\%)=0.097-0.00050 \times \mathrm{TM}(\mathrm{h})
$$

This colour degradation has been considered due to the presence of plants and microbes in treatment reactor. As plants played significant role in dye removal by mineralization and decomposition of contaminants due to the presence of microbes at the rhizoshpere of plants (Lehl et al., 2017), while the presence of bacteria decolourized the azo dye with the reductive breakage of its azo bond $(-\mathrm{N}=\mathrm{N})$, chromophore group, resulting in the formation of aromatic amines (Sing et al., 2015). Additionally, these bacteria have been reported to enhance the growth of plant roots which reciprocally resulted in increasing the growth and metabolic activities of microbes in the rhizoshpere of plants in which these microbes utilized dye as a carbon and nitrogen source (Padmanaban et al., 2013) that boosted up the biodegradation of pollutants. So, plant bacteria combination in this system has been accepted to accelerate the contaminants degradation process (Bais et al., 2003).

\section{Conclusion}

A substantial decrease in all pollutant indicating parameters i.e. BOD, COD and color concentration, of reactive blue dye enriched textile wastewater was found under the treatment of plant-bacteria assisted floating treatment wetlands system. Among all combinations, Eichhornia crassipes and Bacillus cereus, interactive treatment proved its supremacy to make maximum reduction of pollutants. Hence it can be concluded that Eichhornia crassipes and Bacillus cereus synergism can be a plausible approach to treat dye enriched textile wastewater. The existence of Eichhornia crassipes plant in abundance in local climate conditions of Faisalabad and Lahore (Textile industry hubs of Pakistan) increase its credibility to be used for treatment of textile wastewater. Furthermore, this research study unrevealed plant-microbe amplified FTWs technique as an efficient tool to clean textile effluents in green and ecofriendly way and paved the path of its in situ application.

Conflict of Interest. The authors declare that there is no conflict of interest. 


\section{References}

Abed, S.N., Almuktar, S.A., Scholz, M. 2017. Remediation of synthetic greywater in mesocosm-scale floating treatment wetlands. Ecological Engineering, 102: 303-319.

Annuar, M.S.M., Adnan, S., Vikineswary, S., Chisti, Y. 2009. Kinetics and energetics of azo dye decolourization by Pycnoporus sanguineus. Water, Air and Soil Pollution, 202: 179-188.

APHA, 2005. Standard Methods for the Examination of Water and Wastewater, 20 ${ }^{\text {th }}$ edition, American Public Health Association, Wahington, DC, USA.

Arshad, A., Ali, S., Khan, S.N., Riaz, M., Arshad, S., Arslan, Ch., Noor, S., Waqas, M.M. 2017. Design of floating wetland for treatment of municipal wastewater and environmental assessment using emergy technique. Proceedings of the International Academy of Ecology and Environment Sciences, 7: 78-89.

Arslan, M., Imran, A., Khan, Q.M., Afzal, M. 2017. Plant bacteria partnerships for the remediation of persistent organic pollutants. Environmental Science and Pollution Research, 24: 4322-4336.

Asghar, H.N., Rafique, H.M., Khan, M.Y., Zahir, Z.A. 2017. Phyto-remediation of light crude oil by maize (Zea mays L.). Bio-augmented with plant growth promoting bacteria. Soil and Sediment Contamination, 26: 749-763.

Bais, P., Harsh, Vepachedu, Ramarao, Gilory, Simon, Callaway, M., Ragan, Vivanco, M., Jorge. 2003. Allelopathy and exotic plant invasion: from molecules and genes to species interactions. Science, 301: 1377-1380.

Choo, T.P., Lee, C.K., Low, K.S., Hishamuddin, O. 2006. Accumulation of chromium (VI) from aqueous solutions using water lities (Nymphaeaspontanea), Chemosphere, 62: 961-967.

Clark, V. 2004. SAS/STAT 9.1, User's Guide, North Carolina: SAS Institute Inc., Cary, NC, USA.

Faulwetter, J., Burr, M., Cunningham, A., Stewart, F., Camper, A., Stein, O. 2011. Floating treatment wetlands for domestic wastewater treatment. Water Science and Technology, 64: 2089-2095.

Hanson, K.G., Desai, J.D., Desai, A.J. 1993. A rapid and simple screening technique for potential crude oil degrading microorganisms. Biotechnology Techniques, 7: 745-748.

Ijaz, A., Iqbal, Z., Afzal, M. 2016. Remediation of sewage and industrial effluent using bacterially assisted floating treatment wetlands vegetated with Typha domingensis. Water Science and Technology, 74: 2192-2201.

Ijaz, A., Shabir, G., Khan, Q.M., Afzal, M. 2015. Enhanced remediation of sewage effluent by endophyte assisted floating treatment wetlands. Ecological Engineering, 84: 58-66.

Imtiazuddin, S.M., Mumtaz, M., Mallick, A.K. 2012. Pollutants of wastewater characteristics in Textile industries. Journal of Basic and Applied Sciences, 8: 554-556.

Jacobson, C.B., Pasternak, J.J., Glick, B.R. 1994. Partial purification and characterization of 1-aminocyclopropane-1-carboxylate deaminase from the plant growth promoting Rhizobacterium pseudomonas putida GR12-2. Candian Journal of Microbiology, 40: 1019-1025.

Khandare, R., Kabra, A., Kadam, A., Govindwar, S. 2013. Treatment of dye containing wastewaters by a developed lab scale phytoreactor and enhancement of its efficacy by bacterial augmentation. International Biodeterioration and Biodegradation, 78: 89-97.

Lehl, H.K., Ong, Ho.L., Wong, Y., Saad, F.N.M., Oon, Y., Oon, Y., Thung, W., Yong, C. 2017. Decolourization and mineralization of Amaranth dye using multiple zoned aerobic and anaerobic baffled constructed wetland. International Journal of Phytoremediation, 19: 725-731.

Li, Y., Shi, J.Q., Qu, R.J., Feng, M.B., Liu, F., Wang, M. 2012. Toxicity assessment on three direct dyes (D-BLL,DGLN, D-3RNL) using oxidative stress bioassay and quantum parameter calculation. Ecotoxicology and Environmental Safety, 86: 132140.

Merkhali, S.P., Ehteshami, M., Sadrnejad, S.A. 2015. Assessment quality of a nonuniform suspended sediment transport model under unsteady flow condition (case study: Aras river). Water Environmental Journal, 29: 489-498.

Moga, I.C., Ardelean, I., Petrescu, G., Craciun, N., Popa, R. 2018. The potential of biofilms from moving bed bioreactors to increase the efficiency of textile industry wastewater treatment. Industria Textila, 69: 412-418.

Nair, S.S., Swarnalatha, K.D. 2015. Bio-degradation of laundry wastewater. International Research Journal of Engineering and Technology, 2: 789-793.

Noreen, M., Shahid, M., Iqbal, M., Nisar, J., Abbas, M. 2017. Measurement of cytotoxicity and heavy metal 
load in drains water receiving textile effluents and drinking water in the vicinity of drains. Measurement, 109: 88-99.

Padmanaban, V.C., Parkash, S.S., Sherildas, P., Jacob, J.P., Nelliparambil, K. 2013. Bio-degradation of anthraquinone based compounds: review. International Journal of Advanced Research in Engineering and Technology, 4: 74-83.

Patel, S., Vikaskumar, Adhvaryu, R.M. 2016. Removal of textile dye by using Eichhornia spp. and Pistia spp. by aquatic macrophytes treatment systems (AMTS) an eco-Friendly Technique. International Journal of Scientific Engineering and Research, 4: 62-66.

Rafique, H.M. 2015. Bio-remediation of petroleum hydrocarbon contaminated soil in association with plant, Ph.D. Thesis, Institute of Soil and Environmental Sciences, University of Agriculture. Faisalabad, Pakistan.

Rehman, K., Imran, A., Amin, I., Afzal, M. 2018. Inoculation with bacteria in floating treatment wetlands positively modulates the phyto-remediation of oil field wastewater. Journal of Hazardous Material, 349: 242-251.

Saleem, H., Rehman, K., Arslan, M., Afzal, M. 2018. Enhanced degradation of phenol in floating treatment wetlands by plant bacterial synergism. International Journal of Phytoremediation, 20: 692-698.

Shahid, M.J., Arslan, M., Ali, S., Siddique, M., Afzal, M. 2018. Floating wetlands: a sustainable tool for wastewater treatment. Clean-Soil, Air, Water, 46:
$1-13$.

Singh, R.L., Singh, P.K., Singh, P.R. 2015. Enzymatic decolourization and degradation of azo dye- A review. International Journal of Biodeterioration and Biodegradation, 104: 21-31.

Srinivasan, V., Bhavan, S.P., Krishnakumar, J. 2014. Bioremediation of textile dye effluent by Bacillus and Pseudomonas spp. International Journal of Science and Environment Technology, 3: 2215 2224.

Sudha, M., Saranya, A., Selvakumar, G., Sivakumar, N. 2014. Microbial degradation of azo dyes: a review. International Journal of Current Microbiology and Applied Sciences, 3: 670-690.

Tara, N., Iqbal, M., Khan, Q.M., Afzal, M. 2019. Bioaugmentation of floating treatment wetlands for the remediation of textile effluent. Water and Environment Journal, 33: 124-134.

Vymalzal, J. 2010. Constructed wetlands for wastewater treatment. Water, 2: 530-549.

Watharkar, A.D., Khandare, R.V., Waghmare, P.R., Jagadale, A.D., Govindwar, S.P., Jadhav, J.P. 2015. Treatment of textile effluent in a developed phytoreactor with immobilized bacterial augmentation and subsequent toxicity studies on Etheostoma olmstedi fish. Journal of Hazardous Material, 283: 698-704.

Zhang, L., Zhao, L.J., Cui, L.N., Dai1, Y., Kong, L., Wu1, J., Cheng, S. 2016. Enhancing the water purification efficiency of a floating treatment wetland using a biofilm carrier. Environmental Science and Pollution Research, 23: 7437-7443. 